\title{
Culture in Biblical Interpretation: The Use of Yoruba Cultural Elements in Adamo's African Cultural Hermeneutics
}

\author{
Adekunle O. DAdA (University OF IbAdAN, Nigeria)
}

\begin{abstract}
African Cultural Hermeneutics is an approach in biblical interpretation that makes African socio-cultural context a subject of interpretation. This article shows how Adamo has deployed effectively Yoruba cultural elements in the development of this interpretative grid. This is done with a view to determining the extent to which he has engaged successfully the biblical text in a way that has translated to a better understanding of the Bible in Africa. A descriptive approach is adopted as the basic methodology for the article. Yoruba cultural archival resources such as traditions, songs, oracles, folklores and incantations (potent words) are appropriated to make the Bible come alive and relevant. For Adamo, these traditional resources have helped to elucidate the Bible and make its message meaningful for its average reader in Africa. Employing African cultural elements in the interpretative process should however be done with some measured caution.
\end{abstract}

KEYWORDS: David Adamo, Yoruba culture, African Cultural Hermeneutics, biblical interpretation

\section{A INTRODUCTION}

The trajectory of the Bible in Africa is a long and interesting one and the Bible undeniably has exerted enormous influence in some social religious realms in Africa. In view of the strategic importance of the Bible in Africa, different attempts have been made to make its message meaningful for proper internalisation by the average reader. This becomes necessary because of the wider social and linguistics, worldviews and the cultural gaps between the authors of the Bible and the contemporary readers. ${ }^{1}$

One leading African scholar who has attempted to bridge the gap between the time the Bible was written and the contemporary readers in Africa is David

* Submitted: 28/04/2021; peer-reviewed: 08/06/2021; accepted: 20/08/2021. Adekunle O. Dada, "Culture in Biblical Interpretation: The Use of Yoruba Cultural Elements in Adamo's African Cultural Hermeneutics," Old Testament Essays 34 no. 2 (2021): 428 - 444. DOI: https://doi.org/10.17159/2312-3621/2021/v34n2a7.

1 Jeannine K. Brown, Scripture as Communication (Grand Rapids: Baker Academic, 2002), 88-95. 
Tuesday Adamo of Nigeria. Adamo has in the course of his long and fruitful journey as a biblical scholar and an ordained minister in the Evangelical Church Winning All ${ }^{2}$ (formerly known as Evangelical Church of West Africa), proposed different interpretative grids that can be utilised to engage the Bible meaningfully. ${ }^{3}$

One of the biblical interpretative grids which he espoused is what he calls "African Cultural Hermeneutics." According to him, African cultural hermeneutics is an approach to biblical interpretation that makes the African social cultural context a subject of interpretation. It means that African cultural hermeneutics, like any other from the developing world, is carried out always in a particular context. Specifically, the analysis of the text is done from the perspective of an African worldview and culture. Thus, African cultural hermeneutics is the act of rereading the Scripture from a premeditatedly Africentric perspective. The purpose is not only to understand the Bible and God in the African experience and culture but also to break the hermeneutical hegemony and ideological stranglehold that Eurocentric biblical scholars have long enjoyed. ${ }^{4}$

To effectively pursue Africa cultural hermeneutics as an interpretative method and to make the Bible come alive for the African readers, Adamo appeals to the enormous African cultural archival resources. These resources mostly are the traditions, songs, oracles, folklores and incantations of the traditional Africans, mostly circulated orally. For him, these resources can help to elucidate the Bible and make its message meaningful for its average reader in Africa. ${ }^{5}$

This article will examine how Adamo has been able to utilise elements of Yoruba culture in expressing Africa cultural hermeneutics. One of the distinguishing features of the Yoruba is their rich cultural heritage from which Adamo has tapped widely to develop a biblical interpretative method that has helped to understand the Bible and God in the African context. ${ }^{6}$ The article will

2 Evangelical Church Winning All (formerly Evangelical Church of West Africa) is a leading evangelical denomination in Nigeria, founded by the missionaries of the Sudan Interior Mission (SIM) from America and Canada in 1893.

3 To interpret effectively the African context, we must listen to our culture. Bartholomew, in his seminal work, has emphasised the importance of listening in biblical interpretation. See C.G. Bartholomew, Introducing Biblical Hermeneutics: A Comprehensive Framework for Hearing God in Scripture (Grand Rapids: Baker Academic, 2015), 17-47.

4 David T. Adamo, Reading and Interpreting the Bible in African Indigenous Churches (Eugene: Wipf \& Stock, 2005), 46-48.

${ }^{5}$ David T. Adamo, "Decolonizing African Biblical Studies" (Unpublished Inaugural Lecture Delivered at Delta State University, Abraka, 2004), 9-26.

6 Culture has much to do in the interpretive process. For an extensive discussion of this subject, see F.E. Segovia, "Cultural Criticism: Expanding the Scope of Biblical 
also critically assess Adamo's use of Yoruba cultural elements with a view to determining the extent to which he has successfully engaged the biblical text and whether this has translated to a better understanding of the Bible in Africa. Some of the pitfalls of his interpretative grid will also be highlighted.

\section{B A BRIEF EXPLORATION OF YORUBA CULTURE}

To have a deeper grasp of the use of Yoruba cultural elements in Adamo's work, it is helpful to give a brief profile of Yoruba culture. ${ }^{7}$ The Yoruba constitute one of the major ethnic groups in West Africa. They are found mainly in SouthWestern Nigeria, in addition, to some flourishing communities in Benin Republic, Togo and Sierra Leone. The influence of Yoruba culture is also felt in some Latin American and Caribbean countries through the activities of those carried into slavery from Africa into the Americas. The pristine Yoruba culture flourishes in some traditional societies, which include small, isolated and homogeneous groups within the heartland of West Africa. In such societies, people feel they belong together because they share the same kinship group. Broadly speaking, they are kin and cannot freely renounce their membership, for it takes on great emotional meaning for the group as well as the individual. ${ }^{8}$

Before the coming of the colonialists, the above description was the central feature of the different societies that comprised Yorubaland. However, the relevance of the traditional Yoruba culture in modern times can be predicated on the fact that the opposition between modern and traditional society is simply false. There is no completely modern society as there is no completely traditional society. A classic example is found in the first industrialised nation, England, which has learnt how to keep the traditional and blend it with the modern to give

Criticism," in The Future of the Biblical Past: Envisioning Biblical Studies on a Global Key (ed. R. Boer and F.E. Segovia; Atlanta: Society of Biblical Literature, 2012).

7 For a detailed discussion of what constitute culture, see Simon A. Ajayi, "The Concept of Culture," in African Culture and Civilization (ed. Simon A. Ajayi; Ibadan: Atlantis Books, 2005), 4. Elements of Yoruba culture are both "material" and "nonmaterial" in nature. The "material culture" refers to the tangible, concrete and visible human creations. They are elements that can be comprehended by the five senses. They can be seen and touched. These include all human made objects such as tools, weapons, houses, clothes, pots and works of arts as well as all forms of visible production arising from human technology. "Non-material culture" is ideological, made up of all nonphysical or abstract human creations, which are only discernible by the human mind. Examples of this include philosophy, language, oral traditions, ethics, folklores, mythology, values, norms and customs as well as other implicit aspects of any culture. 8 O.O. Taiwo, "Traditional versus Modern Judiciary Practice: Comparative Analysis of Dispute Resolution among the Yoruba Southwestern Nigeria," in African Development 23/3 (1998): 212. 
its development a sense of stability. The same, in the Asian context, could be said of Japan. ${ }^{9}$

The culture of the Yoruba is a pervasive phenomenon because it relates to all aspects of life constituted as the social, religious, economic and political. This is the case because the conception of reality among the Yoruba is holistic. The compartmentalisation of life into the realms of sacred and profane is strange to the average Yoruba whose reality is a unified whole. Central to the cultural matrix of the Yoruba is religion. As Idowu has observed, religion forms the foundation and the all-governing principles of life for the Yoruba. In their thought, the full responsibility of all the affairs of life belongs to the Deity; the role of humans in this framework relates to how one responds to the ordering of the priests and diviners, whom they believe to be the interpreters of the Deity. ${ }^{10}$ The Deity known as Olodumare also work with divinities who are his ministers. These ministers have been employed from the beginning to carry out duties connected with the earth and its fullness. Thus, they are the ministers of Olodumare looking after the affairs of the Deity's universe and acting as intermediaries between the Deity and the world. To each of them is assigned a department over which he or she is ruler and governor. ${ }^{11}$

Additionally, the Yoruba conception of humanity is premised on the interconnectedness of the destiny of humans with the unseen world and the lived realities. It is believed that human actions, activities and achievements are predetermined before the manifestation in real-life situations. This idea is best described in the Yoruba concept of Ori, which is the word for "head." To the Yoruba however, the physical, visible ori is a symbol of ori inu, the "internal head" or "inner person," used in the sense of one's personality. In Yoruba belief, the "ori' rules, controls and guides the "life" and activities of a person, ${ }^{12}$ which therefore explains the premium the Yoruba place on finding out the ori of a newborn child through divination. If the child has a favourable destiny, he/she is guided to achieve their predestined good future.

In terms of the final destiny of humanity, the Yoruba believe that the human life is indestructible. After death, people only transit into a new form of life and the type of life one lives on earth will determine one's state or condition after death. The good and righteous ones are granted the privilege of an earthly presence to offer help to their children and loved ones. They are able to do this because they have been released from all the restraints imposed by the earth.

9 L.J. Munoz, A Living Tradition: Studies in Yoruba Civilisation (Ibadan: Bookcraft Ltd, 2003), xvii.

10 Emmanuel B. Idowu, Olodumare: God in Yoruba Belief (Ibadan: Macmillan Press, 1996), 6.

11 Idowu, Olodumare, 59.

12 Segun O. Ogungbemi, "An Existentialist Study of Individuality in Yoruba Culture," ORITA: Ibadan Journal of Religious Studies XXIV/1\&2 (1992): 102-103. 
Thus, they are the possessors of limitless potential, which may be exploited for the benefit or to the detriment of those who live on earth. ${ }^{13}$ Hence, the people strive to appease the ancestors in order to draw their favour.

\section{YORUBA CULTURAL ELEMENTS IN ADAMO'S AFRICAN CULTURAL HERMENEUTICS}

\section{Motivations for Adamo's Use of Yoruba cultural elements and concepts}

Before examining the elements of Yoruba culture in Adamo's African Cultural Hermeneutics, it may help to consider factors that motivate him to employ such interpretative schema. From an extensive examination of his works, four factors are identified. The first is the need to decolonise biblical studies in the African context. Though the Bible had long been visible in Africa, Western missionaries popularise its usage in modern times. The missionaries, however, interpreted the Bible from the Western cultural perspective. This in essence produced colonised people who have little or no value for their culture, hence, could not engage the Bible from the prism of their culture.

For Adamo, colonialism is a lived and pervasive experience and at various forums he has acknowledged the effects that colonisation had on his world-view and perspective. His experience is best articulated below:

Throughout my years in the Bible College, and seminary in Nigeria I
cannot remember courses in African culture and religion. The only
course in African indigenous religion was taught with the main
purpose of showing how heathenistic and useless the African religion
and cultures are. When I first entered the Bible College in 1968, I was
taught how to sit on the toilet cosmos, how to use toilet papers, how
to dress like Americans and even how to use spoons and forks on the
dining table. But not any atom of the value of African culture was
taught. By the time I graduated I had learned to interpret the Bible the
American ways. I preach the Bible the American ways, and in fact
tried to talk, walk, eat and do everything the American way. More
importantly I learned how to condemn African culture and religion
perfectly well because I was taught that they were not valuable. ${ }^{14}$

For Adamo, this awful situation must be addressed. When the opportunity came for him to practise his skill as a biblical scholar, he placed premium on the traditional culture as a veritable tool of engaging the Bible. Employing Yoruba cultural elements in his works can be justified against this background. To him,

13 Idowu, Olodumare, 107.

14 Adamo, "Decolonizing African Biblical Studies," 10. 
the cultural elements offer a viable opportunity for him to decolonise biblical interpretation in all African contexts.

Moreover, Yoruba cultural elements were adopted in Adamo's interpretative scheme in order to make the Bible relevant in the African milieu. The methodology inherited from the Western missionaries did not take into cognisance the worldview of Africans. The term "worldview" is derived from the German "Weltanschauung," loosely translated also as "world hypothesis" or "world picture," 15 and it is a comprehensive set of assumptions and presuppositions about the ultimate reality of existence. It functions additionally as a "perceptual filter, which can exclude data which would be incompatible."16

Furthermore, adopting Yoruba cultural elements by Adamo in the course of his biblical hermeneutics is an avenue for addressing social and existential needs. In Africa today, poverty, hunger, disease and war are ever-present and threatening realities. These debilitating conditions call for urgent solutions. In this aspect, the African context becomes a compatible subject of interpretation of the Christian biblical messages, with a goal to transform the existential, social, economic, political and religious life of the people. ${ }^{17}$

The fourth motivation for the adoption of Yoruba cultural elements in Adamo's African cultural hermeneutics is to offer a sense of belonging to the people. Having gone through the harrowing experience of colonialism in which the African cultures and persons were unwholesomely and overwhelmingly denigrated, the period following independence was one that sought to raise African consciousness and pride. This mentality was an all-pervasive one. The search for African pride cuts through the social, political and religious spheres. In the area of biblical studies, it is reasoned that one of the best ways to bring African perception to the reading and understanding of the Bible is to engage the traditional cultural elements that take into account the people's existential context. $^{18}$

\section{Yoruba Cultural Elements in Adamo's African Cultural Hermeneutics}

Adamo has employed different Yoruba cultural elements and concepts to engage interpretatively with the Bible. As earlier observed, one reason for adopting these concepts is to make the message of the Bible meaningful within the African

15 John W. Sutterland, A General Systems of Philosophy for Social Science and Behavior Sciences (New York: George Braziller, 1993), 121.

16 Norman Max Wilder, The Theologian and His Universe: Theology in the Middle Ages to the Present (New York: Seabury, 1982), 130.

17 Adekunle O. Dada "Repositioning Contextual Biblical Hermeneutics towards Holistic Empowerment," Black Theology: An International Journal 9/2 (2010): 166.

18 Dada, "Repositioning Contextual Biblical Hermeneutics," 167. 
context. Prominent among Yoruba cultural elements and concepts that feature in Adamo's work are spoken words (incantation or potent words), healing, the aetiology of problems in Yoruba cosmology, spiritual forces, the names of God and Yoruba cosmogony. In this section of the article, how Adamo has employed these concepts in his interpretive task will be probed.

In the traditional Yoruba cultural setting, ofo (incantation or potent words) is the verbal aspect of the magical act with which humans attempt to control both the natural and the supernatural worlds and subject them to their will. It involves the uttering of words according to a formula and in a set order. These words are taken as dating back to time immemorial, in spite of the obvious infiltration of modernity. ${ }^{19}$

In most of his works on the use of psalms in the African Indigenous Churches, especially those in Yorubaland, Adamo has demonstrated how ofo (potent words) can are adapted in these churches. In the healing process in traditional Yoruba society, $o f o$ (potent words), is an important feature. Together with herbs, "the traditional Doctor sometimes gives his client some incantation to chant on the herbal remedies." The use of $o f o$ in Yoruba traditional medicine is predicated on the fact that incantation or potent words can ward off the influence of demonic powers on the sick and the herbal remedies. This belief is strengthened because (potent words) have aṣe (inherent power) to accomplish desired results.

According to Adamo, African indigenous Christians sought religion vigorously for those hidden treasure in the missionary religion that was hidden from them. Using African Cultural Hermeneutics to interpret the Bible, they found that there are secret powers in the Bible especially in the books of psalms. As African Christians sought the Bible to find potent words for protection against perennial problems of witches and all forces of evil, they suddenly discovered some words in the book of psalm that resemble the ones used in African tradition. $^{20}$

In some of the indigenous churches, different psalms are often recommended for different ailments. For stomach pain, Pss 1, 2 and 3 are specially recommended. For these psalms to be effective, the prophets often recommend that the sufferer read the psalm into water, pronounce the holy name

19 Olatunde O. Olatunji, "Characteristic Features of Yoruba Oral Poetry” (PhD Thesis, University of Ibadan, Ibadan, Nigeria, 1971), 197. For detailed discussion of the use of incantation in the healing process, see Obafemi Jegede, Incantation and Herbal Cures in Ifa Divination (Ibadan: African Association for the Study of Religion Publication Bureau, 2010).

20 Adamo, "Decolonizing African Biblical Studies," 24. 
of God, "Walola Asabata Jah,"21 forty-eight times and mix together fried oil, potash, salt and fresh egg and sip it little by little. There is a perfect assurance that the stomach pain will disappear. It should be underscored here that the efficacy of this panacea rest on belief. Even in the West, the deployment of the subjective reality in the healing process has been acknowledged. ${ }^{22}$

On protection, Adamo also notes that some of the psalms are deployed to enhance physical and metaphysical protection. The nature and process of protection employed by African indigenous people are remarkably different from that of the Western world because Africans living on the continent face some peculiar problems due to their perception of the world around them. To the indigenous Yoruba, the presence of witches, evil, sorcerers, evil spirits and all various enemies are painfully real. ${ }^{23}$ To deal with those enemies efficaciously, different incantations are often recited. Some psalms have similar tones and ethos as some of the incantations (potent words) used in similar contexts by the Yoruba.

For example, Ps 35 can be used as potent words, charms and medicine to combat evil forces and to protect oneself against forces of evil. This is because Yoruba Christians believe that psalms such as Ps 35 are irrevocable. Some, especially those in the indigenous churches, write it on their doors, bodies or clothes for protection, with strong faith that it will work. They say it, chant it and believe that it would work for them. Thus, Ps 35 has become a talisman and a psalm for protection, healing and success among some Yoruba Christians. ${ }^{24}$ Similar psalms that can offer healing and protection have been examined extensively by Adamo.

In addition, Adamo has drawn on Yoruba existential aetiology to engage with the biblical text, for example, in his interpretation of Ps 109. Psalm 109 is one of the psalms categorised as imprecatory psalms, that is, psalms in which

21 In the African Indigenous Churches, special 'holy prophets' often claim that special 'holy names' are given to them to unravel the mysteries behind sickness and all forms of misfortunes. "Walola Asabata Jah" is a good example of such names.

22 On the power of belief in the healing process, see Herbert Benson, Timeless Healing: The Power and Biology of Belief (New York: Scribner, 1996), 21-22. Western science and all its brilliant discoveries have been built on the tenet that we can and should want to achieve objectivity and that objective facts can be distinguished from intangible or subjective aspects of life. Moreover, because beliefs and emotions are ephemeral and imperceptible, Western medicine has assumed largely that the effects of one's belief are not physical or measurable. However, neurological research has proved this wrong. It is evident that belief has tremendous influence on the healing process.

23 David T. Adamo, "Decolonizing Psalm 91 in an African Perspective with Special Reference to the Culture of the Yoruba People of Nigeria," Old Testament Essays 25/1 (2012): 16-17.

24 David T. Adamo, "Reading Psalm 35 in African (Yoruba) Perspective," Old Testament Essays 2/3 (2019): 949. 
curses are rained on the enemies. Unlike most Western biblical scholars who label Ps 109 as one of violence, darkness and disorientation. Adamo opines that an excursus into traditional Yoruba understanding of enemies can open up a more meaningful understanding of the text:

Among the Yoruba people of Nigeria there is a belief that every person has at least a known or an unknown enemy called "ota." The Yoruba people distinguish between two types of enemies, "orogun" and "aye." The former is brought about by some perennial quarrels, which come from a variety of circumstances such as land disputes, property inheritance, chieftaincy title disputes, and constant rivalries among wives in polygamous homes. The second type "aye" literally means 'the world.' 'Aye' consists of sorcerers, witches and all persons who are inherently wicked and malicious by nature. ${ }^{25}$

The identity of the enemy could facilitate a meaningful understanding of Ps 109 when read from a Yoruba Christian perspective. The enemies of Ps 109 on whom the psalmist rained imprecation may not necessarily be physical beings, after all. They may be some metaphysical beings such as demons, witches and sorcerers who operate within the ambit of supernatural powers. In relation to the traditional Yoruba existential aetiology, a text like Ps 109 is made to come alive in the consciousness of the people.

Another area Adamo has used elements of Yoruba culture is in the interpretation of the Genesis account of creation. He points out in clear terms the similarities and differences between the Genesis account of creation and Yoruba cosmogony. Most Western scholars have propounded the idea that the Genesis creation accounts possibly have their origin or background in the ancient Babylonian account of Enuma Elish. "But a critical examination of Genesis creation accounts in chapter 1-2," according to Adamo, "reveals that these accounts possibly emerged out of an African context. This is supported by the fact that the creation stories of Africa, especially the Yoruba and Egyptian creation accounts, show that they are closer and have similarities in their themes, motifs among other features." 26

Though there are different versions of the creation stories among the Yoruba, the parallels between the Yoruba and Gen 1-2 creation accounts offer some compelling evidence as to the affinity between the two. For example, in the Genesis account of creation, God is the ultimate creator, while in the Yoruba creation myth, Olodumare is seen as the Supreme Being, with all authority as seen in the Genesis creation account. Another similarity is the existence of a

25 David T. Adamo, "Reading Psalm 109 in African Christianity," Old Testament Essays 21/3 (2008): 582.

26 David T. Adamo, "The Possible African Background of Genesis Account of Creation: Implications for African Christianity," ORITA: Ibadan Journal of Religious Studies XLV/1 (2014): 19-20. 
deep, watery abyss. As in Genesis, a version of Yoruba creation accounts says that a watery marsh covered the earth before Olodumare commanded that some part become dry ground. The creation of humans in Genesis is also similar to that of the Yoruba. According to the Yoruba creation accounts, human beings were created from the dust of the earth. In a Yoruba myth, God gave power to Obatala who moulded human beings from the clay, even when he was drunk; but there was no life until Olodumare, the Supreme Being breathed the breath of life into them. ${ }^{27}$

Another area Adamo has deployed his African Cultural Hermeneutics is in the area of Bible translation. It is assumed that translation is also a form of interpretation; this therefore makes the translation of the Bible into an indigenous language a difficult task. As Mojola has observed:

That Bible translation has enjoyed a privilege place in the history and mission of the Christian Church in Africa as elsewhere is uncontested... Translators are usually the first theologians in any language or community. They have to grapple with all the complex problems arising out of the need to express the ancient and eternal message of the Bible in their own language. They face the challenge of how to translate Biblical concepts, ideas, practices, festivals, rituals, spiritual beings, cultural artifacts, metaphors, beliefs, etc in terms that make sense in the local vernacular. ${ }^{28}$

To Adamo, the name Yahweh was not meaningfully translated into Yoruba language. This is because most of the translators of the Yoruba Bible probably did not understand the original biblical languages and the European supervisors of the translation were not native speakers of the language. This perhaps was responsible for the mistranslation of Yahweh as "Oluwa" in almost all the available translations of the Yoruba Bible.

For Adamo, the divine name Olodumare is preferable and best translated from the Hebrew 'Yahweh.' He hinged his preference for Olodumare on the meaning and attributes of this divine nomenclature in Yoruba. Olodumare has a deeper meaning, similar to Yahweh in his attributes and nature. In the name Olodumare, three words are joined together, 'ol-odu-mare.' While the 'Ol' is a prefix, which means 'owner of' or 'lord of,' “'Odu' literally means 'very large' 'very extensive in greatness, size, quality and worth' or 'superlative in greatness, size, quality and worth" and "mare" is a descriptive adjective meaning 'that does not go,' 'that does not wander' 'that remains.' All these express the qualities of stability, constancy and reliability. Due to the similarities in meaning and attributes of Yahweh and Olodumare in Yoruba religion and tradition, Adamo

27 Adamo, "The Possible African Background of Genesis," 21.

28 Aloo O. Mojola, "Bible Translation in Africa: What Does the New UBS Perspective Have for Africa? An Overview in the Light of the Emerging New UBS Translation Initiative," Acta Theologia Supplementum (2002): 202. 
argues that Yahweh should be translated to Olodumare in the Yoruba Bible instead of Oluwa. ${ }^{29}$

In the same vein, Adamo also observes that Ps 100:3 was not correctly rendered in the Yoruba Bible:

Know that the Lord is God

It is he who made us, and we are his;

We are his people, the sheep of his pasture (NIV).

"Know that the LORD is God" is translated ki eyin ki o mo pe Oluwa oun ni Olorun (so that you may know that the LORD is God). The correct translation would be Mo pe Oluwa oun ni Olorun (know that the LORD is God) without ki eyin ki o mo (so that you may know). This correctly brings out the imperative in Yoruba. It is important that the imperative be clearly spelt out in Yorubajust as the imperative "know that the LORD is God" was an important command for the people of ancient Israel because there were many gods but the only true God is Yahweh. It is also important for Yoruba Christians to know this because there are about 400 divinities (orisa) among the Yoruba. However, Olodumare the Supreme Being has demonstrated his superiority over them in all ways. The result is that Yoruba Christians see Olodumare as the Supreme Being and all other gods as non-existent. ${ }^{30}$

\section{CRITIQUE OF ADAMO'S AFRICAN CULTURAL HERMENEUTICS}

Over the years, Adamo's African Cultural Hermeneutics has been subjected to different criticisms. While some of these criticisms are valid, to some extent, some are seen as emanating from some misunderstandings of the essence of his hermeneutical method. It is in the light of this that I will examine some of the criticisms against Adamo's hermeneutical stance while also offering additional critique of his hermeneutical stance.

One of the major criticisms that I heard of Adamo's cultural hermeneutics was from our revered biblical scholar in Nigeria, the late S.O. Abogunrin. ${ }^{31}$ Abogunrin opined that Adamo's works is a rehash of the traditional African culture in the garb of biblical interpretation. Therefore, the younger generations of scholars should chart a new course that lays emphasis on the

29 David T. Adamo, "Translating the Hebrew name יהוֹה into Yoruba Language of Nigeria in the Yoruba Bible." In die Skriflig 53/1 (2019), a 240, http://doi.org/10.4402/ids.v53i9.2410.

30 David T. Adamo, "Reading Psalm 100 from an African (Yoruba) Perspective," Journal of Semiotics 27/2 (2018): 17.

31 The late Prof. Samuel O. Abogunrin was a leading Nigerian biblical scholar and the founder of the Nigerian Association for Biblical Studies (NABIS). He was a fatherfigure to many biblical scholars in Nigeria including D.T. Adamo. 
evangelical potential of the Bible. Abogunrin's concern was hinged on the fact that, as a leading member of ECWA, the church to which Adamo and I also belonged at that time, Abogunrin opposed any hermeneutical method that may erode the evangelical character of the Bible. His concern even as a scholar that supported contextualisation was that the primal context and content should not overshadow the gospel.

Although Abogunrin's concern was genuine, the fact that elements from the primal context can be adopted to elucidate the Bible was brought to the fore also by Asamoah-Gyadu who claims that,

The indigenous faith of Africa has proved to be a fertile soil for Christianity... it has surfaced most forcefully in the innovative Christian movements established by Africans in response to the intellectualized and over-rationalized forms of Christian expression inherited from Western missions! $!^{32}$

In the same vein, Mbiti observe two prominent features in African Christianity - the use of the Bible, especially in African languages, and the integration of the African worlds with its culture, mentality, spiritual awareness, creativity and modern challenges. Therefore, this interpretation of the Bible and African worlds, as strongly represented and visible in African Christianity, are a major strength, despite the issues it may precipitate as side effects. ${ }^{33}$

On the other hand, scholars such as Riches believe that African cultural hermeneutics propounded by Adamo, as a contextual hermeneutics, poses the problem of normativity. The particularity of a local reading may estrange people from one another. He observes that the imposition of a universal God on other communities might be oppressive and actually lead to the impoverishment of their culture. He stresses also that the particularity of the local reading may contribute to the denial of our common humanity. He contends that we are all caught in the same web of connected humanity and need each other's voices if we are not to deny ourselves by denying our very interrelatedness. ${ }^{34}$

Although Riches' concern is somewhat valid, it should be underscored here that it is indeed difficult, if not outright impossible, to arrive at a uniform or universal reading and interpretation of the text because our contexts, to some extent, influence our readings of the Bible. Our race, culture, gender and class

32 Johnson K. Asamoah-Gyedu, "Drinking from Our Well: The Primal Imagination and Christian Religious Innovation in Africa," Journal of African Christian Thought 11/2 (2008): 41.

33 John S. Mbiti, The Bible and Theology in African Christianity (Nairobi: Oxford University Press, 1992), 228.

34 John Riches, "Interpreting the Bible in African Contexts" in Glasgow Consultation 'Reading with': An Interface between Critical and Ordinary Readings of the Bible (Atlanta: Scholar Press, 1996), 187. 
influence our interpretation of the text. Besides, the Bible also emanated from different socio-cultural and literary contexts. ${ }^{35}$

On a personal note, one of my objections to Adamo's African Cultural Hermeneutics is the disconnection between his hermeneutical theory and the community of faith in Africa, that is, between his theory and praxis, as in most contextual biblical methodologies devised in Africa. They are detached from the community of faith and, therefore, have no direct bearing on the church and the people especially at the grassroots. Since most of the scholars who devise new methods of biblical interpretation are academics from various universities and seminaries, the fruits of their enterprise rarely have direct impact on the ordinary members of the church and society. ${ }^{36}$

In some instances, when using Yoruba cultural elements and concepts, Adamo does not explore widely other options which may be available, for example in translating Yahweh to Olodumare. ${ }^{37}$ The use of divine nomenclature can be viewed against the regional variations in Yorubaland. In the eastern part of Yorubaland, some use the name Oritse, that is, oriise (source of all beings) or Oluiwa (principal of all that exists). These names are mainly used among the Ikale, Ilaje and Itshekiri who in some quarters were reputed to be the earliest inhabitants of Yorubaland. ${ }^{38}$ Peel has cautioned that while dealing with Yoruba culture, scholars should take cognisance of not only the main differences between Northern and Western Yorubaland on one hand and between the Southern and Eastern Yoruba on the other hand but also between the Oyodominated area where Islam was long present and the forest regions where Islam was absent. ${ }^{39}$ In some instances, it may be difficult to universalise a concept in Yorubaland. The first translator ${ }^{40}$ of the Yoruba Bible was from the western part of Yorubaland where Islam was dominant and predated Christianity -his adoption of Oluwa for Yahweh instead of Olodumare can be justified against His background.

35 Dada, "Repositioning Contextual Biblical Hermeneutics," 167.

36 Adekunle O. Dada, "Globalizing African Biblical Hermeneutics: Matters Arising," in The Present State and Future of Biblical Studies in Africa: Essays in Honour of S.O. Abogunrin (ed. J.D. Gwamna, A.O. Dada and H. Amolo; Ibadan: Zenith Book House, 2017), 341.

37 Adamo, Translating the Hebrew Name,

38 James A. Atanda, "The Yoruba People: Their Origin, Culture and Origin and Civilization," in The Yoruba: History, Culture and Language (ed. O.O. Olatunji; Ibadan: University Press, 1996), 15.

39 John D.Y. Peel, Yoruba Religion: Seeing It in History, Seeing It Whole (Ibadan: Institute of Church and Society, 2008), 8-12.

40 The first complete Yoruba Bible was published in 1884. It was translated by the Late Bishop Ajayi Crowther from Osogun in Oyo area in present day Oyo State, Nigeria. He used the Oyo-Yoruba, which later became the standardised Yoruba and the basis of the subsequent study of the language, which has many variants. 


\section{E CONCLUSION}

From the above analysis of Adamo's works, it is evident that his propelling motive for employing Yoruba cultural elements in his interpretation is to make the Bible come alive and relevant in the African context. As a scholar and a preacher of the gospel, Adamo, from my personal interaction with him as my teacher and mentor, has always believed in the transformative potential of the Bible. He, however, believes that the traditional African and archival cultural resources can help unearth the meaning of the Bible for the average readers in Africa. His extensive use of Yoruba cultural resources and elements in the deployment of his African Cultural Hermeneutics may be justified against this background. His goal in the deployment of these Yoruba cultural resources is to address the different problems that the people experience through a meaningful interpretation of the Bible in the African context. As Le Marquand observes:

Biblical criticism that does not labor for the good of the church and of the world is truly a dead letter. For this reason African biblical scholars are explicit that they are reading the Bible with their commitments and interests declared up front. They do not hide hopes that their scholarship may have some kind of impact in a suffering world. ${ }^{41}$

While celebrating this quintessential and cerebral scholar, the onus lies on upcoming biblical scholars following the footsteps of Adamo to be wary of exclusivism. Our interpretative task should be pursued in the light of the global biblical interpretive context. It should be underscored here that those calling for total ousting of Western interpretative methods have missed the point. As Abogunrin stated, "We cannot ignore the two thousand years of Christian heritage in the West and the enormous contribution of Western Christian scholars to the growth of Christian ideas and theology; neither can we dismiss their influence on the life of the Church in Africa." ${ }^{42}$ Nonetheless, the use of African cultural elements in the biblical interpretative process should be done with some measured caution so that a meaning that is neither African in outlook nor biblical in character may not be generated from the biblical text. We should constantly reassess our relationship with the African culture in the light of challenges posed

41 Grant Le Marquand, "The Bible as Specimen, Talisman and Dragoman in Africa: A Look at some African Uses of the Psalms and I Corinthians12-14," in Global Voices: Reading the Bible in the Majority World (ed. E. Yamauchi; Peabody: Hendrickson Publishers, 2013), 112. Similarly, Fiorenza had earlier warned in her Society of Biblical Literature's Presidential Address in 1987 that a value free hermeneutics does the society no good. See Elizabeth Schussler-Fiorenza, "The Ethics of Biblical Interpretation: Decentering Biblical Scholarship," Journal of Biblical Literature 107/1 (1988): 3-17.

42 Samuel O. Abogunrin, "Situation Theology as a Recipe for African Theological Exploration," African Journal of Biblical Studies XV/2 (2000): 2. 
by globalisation. ${ }^{43}$ One of the best ways to do this is to have a defined relationship with one's culture. The relationship between a biblical scholar and the cultural heritage should not be one of uncritical acceptance or total rejection of what can be construed as its central elements. The proper relationship should be one of constructive engagement in which the task of exposition, analysis, criticism, and reconstruction work in partnership. ${ }^{44}$

\section{F BIBLIOGRAPHY}

Abogunrin, Samuel O. "Situation Theology as a Recipe for African Theological Exploration." African Journal of Biblical Studies XV/2 (2000): 2.

Adamo, David T. "Decolonizing African Biblical Studies." Unpublished Inaugural Lecture Delivered at the Delta State University, Abraka, Nigeria, 2004.

. Reading and Interpreting the Bible in Africa Indigenous Churches. Eugene: Wipf \& Stock, 2005. . "Reading Psalm 109 in African Christianity." Old Testament Essays 21/3 (2008): $575-592$.

. "The Bible in Twenty-first Century Africa." Pages 25 -32 in The Africana Bible: Reading The Bible from Africa and the African Diaspora Minneapolis: Fortress Press, 2010

. "Christianity and the African Traditional Religion(s): The Postcolonial Round of Engagement." Verbum et Ecclesia 32/1, Art.\#285, (2011),10 pages doi:10.4102/ve32i1.285.http://dx.doi.org/10.4102/ve.v32i1.285.

. "Decolonizing Psalm 91 in an African Perspective with Special Reference to the Culture of the Yoruba People of Nigeria." Old Testament Essays 25/1 (2012): 9-26.

"The Possible African Background of Genesis 1 -2 Creation Accounts: Implications for African Christianity." ORITA: Ibadan Journal of Religious Studies XLVI/1 and 2 (2014): 1- 32.

. "The Burning Bush (Ex. 3:1 -6): A Study of Natural Phenomena as Manifestation of Divine Presence in the Old Testament and in African Context." HTS Teologiese Studies/Theological Studies 73/3, a4576. https://doi.org/10.4102/hts.v73i3.4576.

. "Reading Psalm 100 from an African (Yoruba) Perspective." Journal for Semotics 27/2 (2018): 23 pages

. "Reading Psalm 35 in African (Yoruba) Perspective." Old Testament Essays 2/3(2019): 936-955.

. "Translating the Hebrew Name into the Yoruba Language of Nigeria in the Yoruba Bible." In die Skriflig 53/1 (2019), https://doi.org/10.4102/ids.v53i9.2410.

. "Translating Psalm 23 in African Context." Verbum et Ecclessia 39 (2018): 1-8, 1a1783. https://doi.org/10.4102/ve.v39i1.1783.

43 A.O. Dada, "Old Wine in New Bottle: Elements of Yoruba Culture in Aladura Christianity," Black Theology: An International Journal 12/1 (2014): 13.

44 Olusegun Oladipo, "Introduction: The Third Way in African Philosophy," in The Third Way in African Philosophy: Essays in Honour of Kwesi Wiredu (ed. O. Oladipo; Ibadan: Hope Publications, 2002), 13. 
Ajayi, Simon A. "The Concept of Culture." Pages 1-11 in African Culture and Civilisation. Edited by S.A. Ajayi. Ibadan: Atlantis Books, 2005.

Asamoah-Gyedu, Kwabena J. "Drinking from Our Well: The Primal Imagination and Christian Religious Innovation in Africa." Journal of African Christian Thought 11/2 (2008): 34-38.

Atanda, J.A. "The Yoruba People: Their Origin, Culture and Civilisation.” Pages 3-36 in The Yoruba: History, Culture and Language. Edited by O.O. Olatunji. Ibadan: University Press, 1996.

Bartholomew, Craig G. Introducing Biblical Hermeneutics: A Comprehensive Framework for Hearing God in Scripture. Grand Rapids: Baker Academic, 2015.

Benson, Herbert. Timeless Healing: The Power and Biology of Belief. New York: Scribner, 1996.

Brown, Jeannine K. Scripture as Communication. Grand Rapids: Baker Academic, 2002.

Dada, Adekunle O. "Repositioning Contextual Biblical Hermeneutics in Africa towards Holistic Empowerment.” Black Theology: An International Journal 8/2 (2010): 160-174.

. "Old Wine in New Bottle: Elements of Yoruba Culture in Aladura Christianity." Black Theology 12/1 (2014): 19-32.

. "Globalizing African Biblical Hermeneutics: Matters Arising." Pages 334-345

in The Present State and Future of Biblical Studies in Africa: Essays in Honour of Samuel Oyinloye Abogunrin . Edited by G.D. Gwamna, A.O. Dada and H. Amolo. Ibadan: Zenith Bookhouse Ltd, 2017.

Idowu, Bolaji E. Olodumare: God in Yoruba Belief. Ibadan: Macmillan Press, 1994.

Jegede, Obafemi. Incantations and Herbal Cures in Ifa Divination: Emerging Issues in Indigenous Knowledge. Ibadan: African Association for the Study of Religion Publication Bureau, 2010.

Kolawole, Oladotun P. "Examining African Hermeneutics and How African Biblical Scholars Have Adopted Western Tools in African Context." World Journal of Education and Humanities 2/1 (2020). Cited 12 January 2021. Online: www.scholink.org/ojs/indexphp/wjeh,33-42.

Le Marquand, G. "The Bible as Specimen, Talisman, and Dragoman in Africa: A Look at Some African Uses of the Psalms and I Corinthians 12 -14." Pages 99-114 in Global Voices: Reading the Bible in the Majority World. Edited by E. Yamauchi. Peabody: Hendrickson, 2013.

Mbiti, John S. The Bible and Theology in African Christianity. Nairobi: Oxford University Press, 1992.

Michael, Mathew. The Old Testament and the African People: Engaging Critical Studies and African Perspectives. Kaduna: Pyla-Mak Publishers, 2015.

Mojola, A.O. "Bible Translation in Africa. What Implications Does the New UBS Perspective Have for Africa? An Overview in the Light of the Emerging New UBS Translation Initiative.” Acta Theological Supplementum (2002): 202-213. "Outstanding Challenges for Contemporary Bible Translation and Interpretation in Africa." Journal of African Christian Thought 10/2 (2007): 3137.

Munoz, Louis J. A Living Tradition: Studies in Yoruba Civilisation. Ibadan: Bookcraft Ltd, 2003. 
Oduyoye, Modupe. The Vocabulary of Yoruba Religious Discourse. Ibadan: Sefer, 2008.

Ogungbemi, S.O. 1992. “An Existentialist Study of Individuality in Yoruba Culture.” Orita: Ibadan Journal of Religious Studies XXIV/ 1\&2 (1992): 50-62.

Oladipo, O. "Introduction: The Third Way in African Philosophy." Pages 11-16 in The Third Way in African Philosophy: Essays in Honour of Kwesi Wiredu. Edited by O. Oladipo. Ibadan: Hope Publications, 2002 . "Characteristic Features of Yoruba Oral Poetry." PhD Thesis, University of Ibadan, Ibadan, Nigeria, 1971. . Features of Yoruba Oral Poetry. Ibadan: University Press Limited, 1984.

Ottuh, Peter O. and Moses Idemudia. "Navigating Trajectories in African Biblical Studies: D.T. Adamo and the Future of African Cultural Hermeneutics." Ianna Journal of Interdisciplinary Studies 2/1(2020): 55-64

Peel, J.D.Y. Yoruba Religion: Seeing It in History, Seeing It Whole: Third Ebenezer Adeolu Adegbola Memorial Lecture. Ibadan: Institute of Church and Society, 2002.

Riches, J. "Interpreting the Bible in African Contexts." 181-188 in Glasgow Consultation Reading with an Exploration of the Interface between Critical and Ordinary Readings of the Bible. Atlanta: Scholar Press, 1996.

Schussler-Fiorenza, Elisabeth. "The Ethics of Interpretation: Decentering Biblical Scholarship.” Biblical Literature Journal 107/1 (1988): 3-17.

Segovia, Fernando E. "Cultural Criticism: Expanding the Scope of Biblical Criticism." Pages 307-337 in The Future of the Biblical Past: Envisioning Biblical Studies on a Global Key. Edited by R. Boer and F.E. Segovia. Atlanta: Society of Biblical Literature, 2012.

Sutterland, John W. A General Systems of Philosophy for Social and Behavioural Sciences. New York: George Braziller, 1993.

Taiwo, O.O. "Traditional versus Modern Judicial Practice: A Comparative Analysis of Dispute Resolution among the Yoruba of Southwestern Nigeria." African Development 23/2 (1998).

West, Gerald. "African Culture as Praeparatio Evangelica: The Old Testament as Preparation of the African Post-Colonial." Pages 193-220 in Postcolonialism and the Hebrew Bible: The Next Step. Edited by R. Boer. Atlanta: Society of Biblical Literature, 2013.

Wilder, Max Norman. The Theologian and His Universe: Theology and Cosmology in the Middle Ages to the Present. New York: Seabury, 1982.

Dr Adekunle O. Dada, Department of Religious Studies, University of Ibadan, Ibadan, Nigeria. Email: ao.dada@ui.edu.ng / kledada@yahoo.com. ORCID: https://orcid.org/0000-0002-6555-9361 